\title{
Capacity Building in Rural Women through Formation and Strengthening of Self Help Groups in Cooch Behar District of West Bengal, India
}

\author{
Soma Biswas ${ }^{1}$, D.C. Roy ${ }^{2 *}$, A. Saha ${ }^{3}$, C.P. Ghosh ${ }^{2}$ and M.C. Pakhira ${ }^{2}$ \\ ${ }^{1}$ Bidhan Chandra Krishi Viswavidyalaya, Mohanpur, Nadia, W.B., India \\ ${ }^{2}$ WBUAFS, Mohanpur, Nadia, W.B., India \\ ${ }^{3}$ College of Agriculture, Lembucherra, Tripura, 799210, India \\ *Corresponding author
}

\begin{tabular}{|l|}
\hline Ke y w o r d s \\
$\begin{array}{l}\text { SHGs, Capacity } \\
\text { building, NRM, } \\
\text { Women } \\
\text { empowerment }\end{array}$ \\
\hline Article Info \\
\hline $\begin{array}{l}\text { Accepted: } \\
\text { 07 April } 2018 \\
\text { Available Online: } \\
\text { 10 May 2018 }\end{array}$ \\
\hline
\end{tabular}

\section{A B S T R A C T}

Capacity building in rural women through formation and strengthening of SHGs was experimented at Khagribari, Dhalaguru and Dhandingguri villages of Cooch Behar district of West Bengal during 2012-15 with an objective to motivate the rural women to involve in different rural development programmes. Before the start of the trial most of the women were mere housewife and performed agricultural and allied activities in their own farming situation. Many of them were not the member of any group or organization. Beside, a number of SHGs are in existence but without any group activity. Azolla cultivation as Capacity Building through NRM, backyard duckary, multistoried cropping in homestead fallow land for generation of extra income, handicrafts on dye and tie, batik and fabric painting were some of technological interventions. Monthly savings, Loan repayment, discussion on different family welfare activities like child health care, children education, care of girl child etc. were some initiatives for economic empowerment. Social and psychological empowerment on various social issues were identified by the activities like celebration of social activities like tree plantation, independence day celebration etc., busyness in Azolla units, handicrafts units and other group activities, interested in training on new aspect, awareness about various social issues, easy and frequent movement to bank. Formation and strengthening of SHGs is most important in rural India as empowering of women is most important for empowering Nation.

\section{Introduction}

In the developing countries like India, women have always been given a secondary status whether at home or in the society.

They are lacking of four basic things and these four things are knowledge, finance, power and opportunity. Self-help groups fulfil the four criteria cited - thereby making them financially stable and also granting them a sense of empowerment. SHGs are novel and innovative organizational setup in India for the women upliftment and welfare.

All women in India should be given chance to join any one of SHGs for training and development, so as to be prospective entrepreneur and skilled worker. India's Self Help Group (SHG) movement has emerged as 
the world's largest and most successful network of community based organizations (CBOs). It is predominantly a women's movement.

Evidences from various developing countries throughout the world have shown that the poor can be helped by organizing themselves into Self Help Groups. Deininger and Liu (2009) pointed out that SHG has a positive impact on female empowerment and on household income. Self Help Groups have the following advantages:

They encourage the poor to save. The poor become creditworthy and bankable customers and are not seen as beneficiaries. They reduce the transaction cost of lenders and borrowers.

Women are trained in new skills and technologies and the wage earning workers become micro entrepreneurs.

They help the poor to gain economic and social empowerment. Increased asset creation and savings, higher employment and improved social lives of members are the benefits to the members.

Keeping all these in view the present study was conducted in the villages of Cooch Behar district of West Bengal during the years from 2012 to 2014. In village Khagribari, Dhalaguri and Dhandinguri women are mostly housewife. In addition to their household work many of them also perform agricultural and allied activities in their own farming situation. They are very interacting among themselves. Many of them were not the member of any group or organization. They were like small islands, floating side by side but never joined. They heard about the existence of SHGs, but did not have any idea about the formation and activities of SHGs. Besides, a number of SHGs are in existence but without any group activity.

\section{Materials and Methods}

\section{Formation of SHGs}

A group meeting cum awareness programme was organized by taking help from Cooch Behar KVK to assess their need and interest for SHG formation and to find out interested women.

The interested and needy women were called for a training to make a concept about formation and activities of SHG.

After a detailed going through, total 34 women divided themselves into 3 groups (Group $\quad \mathrm{A}=12$ no./Gr-B=12/Gr.C=10) depending on the following criteria:

Nearness of houses

Social intimacy

Mental closeness

In the presence of scientists as facilitator, each group chose their President, Secretary and Treasurer among group members.

With the agreement of all members each group chose group name. (Group

As per the guideline of SHG formation the groups made group rules and took first resolution.

Each member of three groups started a monthly saving of Rs. 100.00

After three months the groups opened bank account for each group and started to put their saving in bank.

2 months after opening the account the groups started to use their bank savings to provide loans within among the group members. 
Monthly savings as well as loan repayment with interest is going on.

Now the groups have submitted their all documents to Panchayat for grading so that they may become eligible for government loan and subsidy.

\section{Strengthening of SHGs}

An initiative was taken to create awareness about the different group activities among the members of different existing groups.

Groups having active and enthusiastic members took the opportunity and were called for different capacity building programmes organized through this experimentation.

Present study was conducted at the villages of Cooch Behar district of West Bengal namely Khagribari, Dhalaguri and Dhandingu during the years from 2012 to 2015 .

\section{Results and Discussion}

Interventions towards technological
Empowerment

Azolla cultivation: $\begin{array}{r}\text { Capacity } \\ \text { building } \\ \text { through NRM } \\ \text { Management) }\end{array}$

Azolla can be cultivated not only as biofertilizer but also as cattle feed.In addition to its traditional cultivation as a bio-fertilizer for wet land paddy, Azolla is finding increasing use for sustainable production of lives stock feed. Azolla technology if once introduced, get integrated with farmyard and homestead activities through sustained results. 4 SHGs from Dhalaguri and 2 SHGs from Khagribari village were initially selected. Several trainings were organised and the same were aided by audio-visual means. After training the women were guided and assisted to make their own Azolla production units. Field days were also organized by involving the members of other SHGs and interested women of the said villages along with Krishi Prayukti Sahayaks (KPSs), different panchayat functionaries and important personnel of the locality. Women started to feed their cows with Azolla 20 days after cultivation. It has been estimated that two Azolla pits of said dimensions are necessary for continuous feeding of a single cow. Observations were taken on feed cost and average milk quantity after continuous feeding with Azolla for three months. It was observed that the amount of paddy straw and rice bran could be decreased to a considerable extent when $1 \mathrm{~kg}$ of Azolla was added in feed items as a supplementary feed and inclusion of Azolla in feed items resulted in a saving of Rs. 4.00 (Rs 22.50 without Azolla and Rs. 18.50 with Azolla) per cow per day. Therefore, there is monthly saving of Rs. 120.00 per cow towards expenditure in feed cost.

In village socio-economic perspective monthly savings of Rs.120.00 per cow is a satisfying factor or in other word capacity building factor for rural women, there was an average increase of $15.04 \%$ in milk yield with inclusion Azolla in feed items. Increase in milk yield with less feed cost was supposed to be a key factor for creating huge enthusiasm among the rural women (Table 1 and 2).

\section{Backyard duckery: Source of an additional income}

Women were trained on the rearing of Khaki Campbell duck as a source of an additional income. Rearing of Khaki Campbell is profitable for the north Bengal farming situation. The ducks lay 300 eggs in a year and egg size is larger in compare to Local varieties. 21 days old ducklings were given to the members of SHGs who were already trained on rearing of Khaki Campbell. At the 
age between 18 and 22 weeks the females start laying. The selling price of egg is Rs. 6.00 per egg. The data was taken for continuous one year. It was found that women started to get average an income of Rs. 160.00 per month.

\section{Multi-storied cropping in homestead fallow land for generation of extra income}

Fallow and unutilized lands are there adjacent to most of the village households. This land area is mostly under the care and control of female part of the family. These areas can be utilized efficiently by women for economic return. Multistoried cropping pattern can be a best option for this purpose. Training programmes on multistoried cropping pattern for the member of SHGs were also organized. After training, under the guidance of us, many of them have started the cultivation of crops like turmeric along with the plantation of Areca nut. Their future programme was to grow Black Pepper around the Areca nut for better economic return.

\section{Handicrafts on dye and tie, batik and fabric painting}

Handicrafts on Dye and Tie, Batik and Fabric painting can be a sustainable business unit for sustainable economic empowerment of SHGs. With a view to enhance the skill of women SHGs we decided to train 50 women in the making of Handicrafts on Dye and Tie, Batik and Fabric painting. Taking the help from Cooch Behar KVK, we organized a 3 phased training programme under the guidance of experts. After training the trained members have started to make the products on Tie and die, Batik and Fabric painting. Initially they started to sell the product in different institution of local area like schools, BDO office, and different line department offices of the block. Initiative had been taken to develop backward and forward linkage with the different marketing organization for developing marketing channel.

\section{Economic empowerment}

Each group organized monthly meeting in the first week of each month.

In the presence of experts group performed the following activities:

Monthly savings: One of the primary benefits of participation in a SHG is the opportunity to save regularly, access formal savings institutions and participate in the management of these savings.

They started to save regularly, have their own bank accounts and make deposits into these accounts. SHG is having a good impact on members, in their ability to save their hard earned money

Loan repayment: reports have shown that the record on the repayment of loans by women was often better than that of men, and that women are also more likely to spend the income earned, on their families, leading to improved health and nutrition of the poor population and for improving the quality of their lives.

\section{Use of loan taken by the members of SHGs}

Buying poultry birds

Buying materials for Azolla cultivation

Buying materials for Handicrafts

Cucumber cultivation

Children education

\section{Social and psychological empowerment}

\section{Decision-making within the household}

There is an increased involvement of members in decision-making, awareness about various programs and organizations, increased access to such organizations, increased expenditure on Health and Marriage events. 
Table.1 Comparison of feed cost (Average feed cost/day/cow)

\begin{tabular}{|c|c|c|c|c|c|c|}
\hline \multirow[t]{2}{*}{ Feed items } & \multicolumn{3}{|c|}{ Cow feed with Azolla } & \multicolumn{3}{|c|}{ Cow feed without Azolla } \\
\hline & Quantity & Rate (Rs.) & $\begin{array}{l}\text { Total amount } \\
\text { (Rs.) }\end{array}$ & Quantity & Rate (Rs.) & $\begin{array}{l}\text { Total amount } \\
\text { (Rs.) }\end{array}$ \\
\hline Paddy straw & 10bundles & $1.00 /$ bundle & 10.00 & 12 bundles & $1.00 /$ bundle & 12.00 \\
\hline Rice bran & $2 \mathrm{kgs}$ & $4.00 / \mathrm{kg}$ & 8.00 & $2.5 \mathrm{kgs}$ & $4.00 / \mathrm{kg}$ & 10.00 \\
\hline Azolla & $1 \mathrm{Kg}$ & - & & - & - & - \\
\hline Salt & $100 \mathrm{~g}$ & $5.00 / \mathrm{kg}$ & 0.50 & $100 \mathrm{~g}$ & $5.00 / \mathrm{kg}$ & 0.50 \\
\hline Grasses & - & - & - & - & - & - \\
\hline Total & & & 18.50 & & & 22.50 \\
\hline
\end{tabular}

*average of three years data

Table.2 Comparison of milk yield (Average milk yield/day/cow)

\begin{tabular}{|c|c|c|}
\hline Cow fed with Azolla & Cow fed without Azolla & Percentage increase \\
\hline 1.30 Litre & 1.13 Litre & 15.04 \\
\hline
\end{tabular}

*average of three years data

There is a change in the attitude of male members of the families, now they are convinced about the concept of SHG and encourage women to participate in the meetings and women reported that they have savings in their name and it gives them confidence and increased self-respect.

We organizes training programme for the SHGs members on different aspects from time to time. Within family the respect and status of women has increased. Children Education has improved significantly. Especially girl education was very low but now SHG members are sending their children including girls to school. The sanitation in member's households has improved and it has led to better health in members' families. Now women are taking treatment from qualified doctors, even if they have to travel to nearby towns. Members are now confident enough to raise social status.

\section{Communication level of members}

Communication ability of the members has improved significantly, their ability to express their feelings and this has made people more confident to express themselves.

\section{Self confidence among members}

The group formation brought out the hidden talent and leadership qualities among the members. After joining the SHG the members have improved their status in family, became helpful in family finance and sometimes help others too.

Now, the members of those SHGs feel that they get more respect; not only in the village, but our own family members treated them more respectfully. People of the village now invite them for social and community functions. Now their family members value their opinions whereas earlier they had no use for it. They encourage the women and support them for their activities. They have improved their knowledge of banking, of how to undertake the different banking transactions, as also of dealing with government officials. They now feel confident about these things. They too feel an improvement in their social status.

\section{Change in family violence}

Involvement with SHG has reduced this violence. The members revealed that their husbands should also be involved in SHGs. 


\section{Community participation}

SHG members have undertaken a lot of community activities which they earlier could not have imagined themselves to have done. They undertook a plantation drive.

They participated in several social initiatives like the "Clean Village Drive" and other such social upliftment programme since their involvement in the SHGs. They organized a small function on India's Republic day.

The study shows that the main reason for joining SHG is not be merely to get just credit, it in an empowerment process. After joining the self-help group the women are economically and socially empowered. This empowerment cannot be transformed or delivered.

It must be self-generated such that it enables those who are empowered to take control over their lives. SHG Programme clearly plays a central role in the lives of the poor. Standard of living for the program participants has increased and also the food security is much more for the program clients.

Programme activities are one of the main ways to overcome food insecurity with sickness, disease, emergencies and crises, where programme participants seem to transfer the loan source from friends and moneylenders to SHG loans to meet these expenses. The process of empowerment manifests itself in increased self-esteem. Programme participation is also associated with changes in decision-making at the family level. The Self Help Groups have proved the way for economic independence of rural women.
Thus, it can be concluded that the self-help groups contribute substantially in pushing the conditions of the female population up and through that chip in poverty eradication as well.

\section{Acknowledgement}

The authors acknowledge the authorities and officials of BCKV for providing the necessary facilities for conducting the experiments.

\section{References}

Lakshmi, R. and Vadivalagan. G. Impact of Self Help Groups on Empowerment of Women: A Study in Dharmapuri District, Tamilnadu. (Retrieved from www.jms.nonolympictimes.org/Articles/5 .pdf on 14.08.2016)

Manisha (2016). Impact of Self-Help Group in Socio-Economic Development of India.In. Proceedings of $4^{\text {th }}$ International Conference on Recent Innovations in Science, Engineering and Management. India International Centre, New Delhi, March 20, 2016, pp 1145-51.

Rajendran, K. (2012). Micro Finance through Self Help Groups: a survey of recent Literature in India. Journal of Marketing, Financial Services \& Management Research, 1 (12): 384-92.

Reddy and Reddy (2012). Self Help Groups in India: A Study on Quality and Sustainability. Journal of Marketing, Financial Services \& Management Research, 1 (12): 345-56.

\section{How to cite this article:}

Soma Biswas, D.C. Roy, A. Saha, C.P. Ghosh and Pakhira, M.C. 2018. Capacity Building in Rural Women through Formation and Strengthening of Self Help Groups in Cooch Behar District of West Bengal, India. Int.J.Curr.Microbiol.App.Sci. 7(05): 794-799.

doi: https://doi.org/10.20546/ijcmas.2018.705.096 